\title{
THE PLOT OF THE "TYPICAL" ROMAN COMEDY: ANCIENT SCOPE AND MODERN FOCUS
}

\author{
Z M Packman (University of Natal, Pietermaritzburg)
}

One point of continuing interest in the study of the Roman comic writers is the unequal status of male and female in the tales of young love so often encountered in the texts. While the young man in love is almost invariably both free and of citizen class, the young woman with whom he wishes to be united, reunited, or continuing in union is sometimes both free and of citizen class, sometimes free but not of citizen class, and sometimes a slave. In a few cases a young woman apparently belonging to one of the latter two classes turns out to belong in fact to the first. The problems attendant upon each love story, and to some extent the outcome of each, depend in large part on the status of the young woman involved.

Plutarch, speaking of Menander's plays, gives a round summing-up of love objects and love outcomes (Quaest. conv. $712 \mathrm{C}$ ):

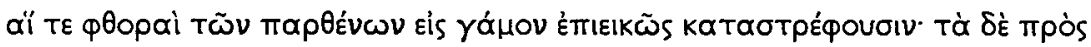

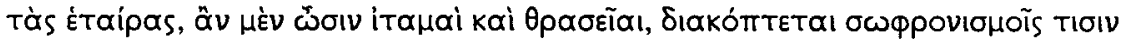

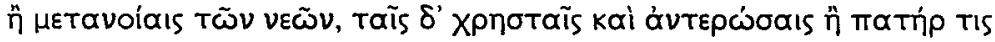

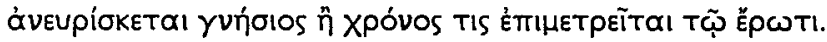

Ravishings of marriageable girls are suitably converted to marriage; as for unmarriageable girlfriends, if they are aggressive and demanding, dealings are cut off by some chastisement or change of heart on the parts of the young men, while for those who are decent and loving, either some legitimate father is discovered or some additional time is allotted to the affair.

Noticeably absent in this summing-up is any distinction, in the category of unmarriageable girlfriends, between those of slave status and those of free, but noncitizen status. The specific status of the unmarriageable girlfriend is made clear in each Roman-comedy love story, but this depends on explication, since in these texts the term meretrix is applied equally to free aliens and slaves. Anderson (1984), in an intensive comparison of Plutarch's remarks with what is known of the work of Menander, notes that, even in the Greek original, unmarriageable girlfriends - hetairai - might be either free or slave.

Other specialized studies of ancient comedy, both New and Roman, are often attentive to distinctions in status of love object and outcome of affair. ${ }^{1}$ But scholars describing or summarizing the plots of Roman comedy, or its Greek antecedents, in works of broader scope often simplify in such a way as to eliminate all but one class of young woman involved in these love stories, and all but one sort of outcome of the affairs. It is my purpose in what follows below to trace this tendency in modern

l So, notably, Fantham 1975 and, for the works of Terence, Levin 1967. 
discussion, test it against the love stories in the Roman comedy originals, and reflect on the discrepancies thus revealed.

The sort of young woman specified as love object in many modern descriptions of Roman comedy plots is the last in my own set of categories - the one seeming at first to belong to the class of unmarriageable girlfriends, but turning out in the end to have local family links which make her legally free and of citizen class, and therefore marriageable; the sort of outcome specified in such plot descriptions is marriage of lover and beloved. Nairn (1924:15), speaking of New Comedy as represented in the Roman versions, gives this indication of the usual plot line: "The action depicts the efforts of a youth to obtain possession of his mistress, often in face of the opposition of a parent or guardian, and with the assistance of a tricky slave. Recognition of the heroine is frequently the result of the discovery of various tokens, which have been attached to her when she was exposed in her infancy. The marriage of the heroine (when discovered to be a well-born maiden and an Athenian citizen) to the hero follows as a matter of course." With or without the characters and events specified as bridging the transition from opening to closing situations, comparable representations of the Roman-comedy love plot are found in modern authors both earlier and later than Nairn, as, for example, in Fowler (1903:18-19) on Plautus: "The plots of his plays, as those of Terence, are usually founded upon a love affair between a young man of good family and a girl of low position and doubtful character...In the end, the lovers are usually united, and the girl turns out to be of good birth, often the long-lost daughter of one of the older men in the play," and in Beacham's on Plautus (1992:30): "Often the plot centred on the love affair of a well-to-do young man, who after some not too unseemly adventures discovers that the object of his affections is (despite first impressions) a fit choice for marriage."2 Similar descriptions of the Roman comedy plot, or its New Comedy exemplars, can be found in publications ranging from encyclopedias (e.g. Rose 1968:804-805) to annotated editions (e.g. Ashmore 1967:5).

And while the kinds of plot descriptions cited above seem to single out one of several known objects of a young man's love in Roman comedy plots - the seemingly unmarriageable girl, slave or free, who turns out to be marriageable after all - there is a still greater number of modern publications which further narrow the range of Roman-comedy love-objects by specifying slave status for them. Norwood's (1932:11-12) formulation is particularly well known: "They both [Plautus and Terence] treat the same theme. Their methods of handling it differ immensely, but their starting-point in most of the twenty-six comedies varies only in detail." Norwood then offers a "composite photograph" of the plots of the Roman comedies: "A young Athenian is in love with a charming but friendless girl who is the purchased slave of a leno, or professional procurer...all is put right by a sudden revelation that the heroine is really of Athenian birth (but kidnapped or lost in babyhood) and can therefore marry the hero." And Norwood's characterisation of the young woman involved in the Roman-comedy affair, and the outcome of it, is echoed by many a

2 Compare von Albrecht 1997:183: "Most often a young girl regarded as a hetaera, or threatened by that fate, is revealed as the daughter of an Athenian citizen so that her lover can marry her." 
modern author, before him and after. So, for an early example, Pichon (1897:60): "Nearly all the plays can be summed up in a few words: there are a series of tricks arranged by a rascally slave to promote the success of a young lover and a woman who, as a rule, is found to be of free status."3 At a much later date, Paratore (1961:46) has this to say of New Comedy, as represented by Plautus: "Attic New Comedy had the defect of being frozen into stereotypical themes, situations, and character types: its almost invariable plot consists in the desperate efforts of a young man of good family, but reckless and pleasure-seeking, to remove from the custody of an extortionate pimp a young girl of whom he is enamored... a final recognition scene brings about the discovery that the young man's beloved is the daughter of a respectable man, usually a friend of the boy's father, and therefore worthy to become his wife."4

Nearer our own time, Howatson (1989:444) offers this on Plautus: "Most plots centre on the tricks of a resourceful slave to forward the love-affair of his young master who is being thwarted by a rival, a pimp, or a stern father. The girl in question is usually a slave-prostitute who is eventually discovered to be free-born and so able to marry her Athenian lover," while Zehnacker and Fredouille (1993: 32), also on Plautus, give the following version: "The general outline of the plays is regularly based on the reciprocal love of a young man for a courtesan or a young girl kidnapped from her family and held by a pimp... The intrigue often ends with a recognition scene: it is discovered that the girl is of free birth, the pimp is dispossessed and dismissed with ridicule... and the young people marry the same day." This kind of summary of the common or garden-variety Roman comedy plot is not only found in general works on Latin literature, like most examples quoted above, but also in works ranging from encyclopedias (Taladoire 1989:472) to annotated textbooks (Moseley \& Hammond 1933:9).

The recurrent representation of the typical Roman comedy plot as one in which a young man's beloved is a slave girl eventually found to be free and marriageable - or a girl of unmarriageable status, whether slave or foreign - can readily be tested against the surviving plays of Plautus and Terence. ${ }^{6}$ To begin with Plautus, it appears that there are seven Plautine plays in which the object of a young citizen's love is a slave girl (Casina, Curculio, Epidicus, Mercator, Poenulus,

3 "Presque toutes les pièces epuvent se résume en deux mots: ce sont des suites de ruses ourdies par un fripon d'esclave pour amener le triomphe d'un jeune amoureux et d'une femme qui, généralement, est reconue de condition libre."

4 "La commedia attica nuova aveva il difetto d'essersi cristallizzata in temi, situazioni e tipi stereotipi: il suo canovaccio quasi abituale consiste negli sforzi compiuti da una giovano di buona famiglia, ma scapato e godereccio, per sottrarre alla custodia di un lenone ricattatore una fanciulla di cui egli si è incappricciato... una finale cognizione fa scroprire che la fanciulla amata dal giovane è figlia di un uomo dabbene, di solito amico del padre del giovanotto, e quindi degna di diventare la sua sposa."

5 "Le canevas général des pièces est d'ordinaire fondé sur l'amour contrarié d'un jeune homme pour une courtisane ou une jeune fille enlevée à su famille et prisonnière d'un leno...L'intrigue se termine souvent par une scène de reconnaissance: on découvre que la jeune fille est de naissance libre, le leno est dépossédé et bafoué...et les jeunes gens se marient le jour même."

6 Texts cited are, for Plautus, Lindsay 1903; for Terence, Kauer \& Lindsay 1926. 
Pseudolus, and Rudens), and that the free and citizen-class parentage of the girl is established in five of these cases. In four, the outcome is the marriage of lover and beloved (Casina, Curculio, Poenulus, and Rudens), while in the fifth (Epidicus), the beloved proves to be the sister of the would-be lover. In two other comedies (Mercator and Pseudolus, to which Epidicus should perhaps be added as a third case, if, as seems likely, we are to understand that the young man of the piece is reunited with his original girlfriend), the slave girl remains a slave girl, and is united with her lover in slave concubinage.

Other objects of a young man's love in the Plautine corpus are the free and citizen-class girl, in one play only (Aulularia, to which the subplot of Truculentus might be added as a second case, with the reservation that the young man involved is actually in love with someone else) and the free but non-citizen meretrix, in five plays (Asinaria, Bacchides, Cistellaria, Miles Gloriosus, and Truculentus). Where the object of desire is the free and citizen-class girl, the outcome is marriage. Where she is a free but non-citizen meretrix, there is one case in which she is discovered to be of citizen class after all, and so marriageable (Cistellaria), while in three cases the happy ending consists of a continuing love affair. In Truculentus, the lover is made to marry another, but promises to keep visiting the unmarriageable girlfriend.

In Terence, because of the double structure of the plots, there are perhaps nine conventional love stories found in five plays, disregarding Hecyra, which begins with the hero married, and the underdeveloped second love story of Andria. In only two of these (Phormio and Adelphoe) is a slave girl the object of a young man's love - and in both cases the affair ends in the lover's purchase of the girl, and slave concubinage. In two of Terence's love stories (Phormio and Adelphoe), a citizen-class girl is the object of a young man's desire, and the outcome in each case is marriage. In two cases (Heauton Timorumenos and Eunuchus), a young man is in love with a free, noncitizen meretrix. In Heauton Timorumenos, the relationship ends in separation, with the young man negotiating - under parental pressure - a marriage with a citizen-class girl not seen or heard of until the end of the play. In Eunuchus, the relationship continues as an affectionate, but also commercial, affair. In three of Terence's plays (Andria, Heauton Timorumenos, and Eunuchus), young women who at first appear to belong to the class of free but non-citizen women prove in the end to belong to the citizen class; in each case, the relevant love affair ends in marriage.

Although, as seen above, the typical Roman comedy plot is often described as one featuring a slave girl who turns out to be free, and is married to her lover, this story is relatively uncommon in the surviving literature. Among the plays of Plautus, it is only in four out of twenty (or, perhaps more fairly, four out of the thirteen where the loves of unmarried youth are at issue) where this occurs, while in the six plays of Terence (or five where the loves of unmarried youth are at issue) there is no example of it. With reference to other modern plot descriptions mentioning only a girl thought unmarriageable (whether free or slave), but eventually found to be marriageable after all: this occurs five times in the plays of Plautus (four slave girls and one free but of non-citizen status), and three times in the plays of Terence (free but non-citizen-class girls in each case), for a total of eight plays offering this kind of love story in the 
corpus of Roman comedy - eight out of twenty-six plays, or eight out of twenty-two love stories there recorded.

By comparison, there are eleven love stories in the corpus of Roman comedy where a girl who at first appears to be unmarriageable turns out to be in fact unmarriageable. Where the girl is of slave status, the affair ends in concubinage. Where she is of free but non-citizen status, it leads normally to an open-ended association, only once or twice (Heauton Timorumenos and perhaps Truculentus) to separation. The girl known to be marriageable is least often found as the object of a young man's attentions in the Roman-comedy love stories: four times, including Truculentus, each time with marriage the outcome of the affair. Plutarch's observations on objects and outcomes of love in Menander, as set out at the beginning of this essay, might almost be read as a frequency chart, in ascending order, for objects and outcomes of young men's love in Roman comedy: marriageable girls less often involved than others, but affairs involving them always ending in marriage; unmarriageable girls more often involved, with outcomes, in ascending order of frequency, being separation, marriage after discovery of free and citizenship status, or continued association on terms other than marriage.

It is to be noted that not every modern description of the Roman comedy love plot specifies an outcome in marriage after an unanticipated discovery of eligibility on the part of the young woman involved. Most specialist studies have no reason to offer any kind of plot summary, and more comprehensive studies sometimes offer a typing of comedies based on other factors. Even the authors offering such summaries often go on to acknowledge that the corpus of Roman comedy offers a good deal of variance from, or on, the plot described as typical - and this in addition to a good deal of hedging in the original description. The recurrence of words like "often" and "usually" is noticeable in the passages quoted earlier in this essay.

The kind of plot offered as typical in the works quoted above has not gone entirely without challenge, though published examples are sometimes ambivalent. Duckworth (1952:28), has this to say of New Comedy and particularly Menander: "The basis of each play is a love story, and portrays the love of a young man for his neighbor's daughter or for a mistress whose true identity is later revealed...", but later in the same work (1952:140) criticizes Norwood's "composite photograph" as quoted above, on the grounds that, while each feature in it is common enough, the linkage suggested between them "combines the elements of mistaken identity and trickery in a manner seldom seen in the comedies themselves." Konstan first offers, then critiques, and finally settles for a partial validation of the traditional version of the typical Roman comedy plot. So (1983:24), "The typical story in which a young man, against the wishes of his father, falls in love with a woman who is a slave, foreigner, or otherwise ineligible as a legitimate partner in marriage, is commonly resolved by means of a recognition scene, in which she is revealed to be a citizen of suitable status;" but later (1983:26) after quoting Ashmore, as cited above, "Ashmore's description applies to only a small percentage of the surviving Roman comedies, however." Konstan goes on to suggest that the traditional version of the typical 
comedy love plot is valuable to the understanding even of comedies where it is not in play.

Levin (1967:302), in an article dealing specifically with the plays of Terence, challenges directly the generalized plot description so well established in the literature, at least as it applies to his author. Citing some of the texts quoted above, Levin states: "All formulations of this type, it can be seen, conflate the two distinct kinds of romantic attachment and of dramatic action which Terence has managed to separate by his dual structure." Anderson (1995:178) more recently lays down a decided, though by-the-way, challenge to the regular characterization of the females beloved by Plautine youths: "The point is, Plautus...inclines us against the selfish father but also against the helpless son in his silly love affairs, almost always, it should be noted, with a confirmed prostitute and not with a kidnapped free girl." And Wright (1982:521), writing on Plautus, refuses to endorse any general description of that author's plots: "It will be clear from our examination that there is no such thing as a typical Plautine comedy."

In view of the actual objects and outcomes of young men's loves in the Roman comedies, as listed above, it might be argued that Duckworth's and Konstan's strictures do not go far enough: it is not only the complications of the plot, but its original terms and its outcomes that are misrepresented in the summaries cited, and there is no good reason to conclude that the kind of plot these summaries represent is more basic or significant than others found in the comedies. Levin's observations, for Terence, are strictly correct, while Anderson's, for Plautus, may be overstated. In only six of the thirteen Plautine love stories is the object of affection a "confirmed prostitute" in the sense that no marriageable background is either known or discovered for her.

Meanwhile, against the background of such occasional criticism, mainstream representations of Roman comedy love stories continue, as seen above, to offer as typical the case in which a young man's love for an apparently unmarriageable girl leads, after complications and reversals, to the discovery that she is after all of marriageable status, and a happy ending in marriage. And this is, as shown, not the commonest love story in the corpus of Roman comedy.

Love of a young man for an unmarriageable girl, leading, after complications and reversals, to continued association on terms other than marriage: that is the commonest love story in the corpus of Roman comedy. If modern treatments of the Roman comedy tend to single out as typical the second most common love story in the corpus - love of a young man for an apparently unmarriageable girl, who turns out, after complications and reversals, to be marriageable after all - the reason must lie in the interests and preferences of the modern commentator, and the presumed interests and preferences of his audience. Most obviously, it would appear that there is a modern preference for love stories which end in marriage, as opposed to those which unite lovers in some other kind of relationship - or a disinclination on the part of moderns to accept and approve a relationship of slavery and slave-ownership between young lovers, or one which involves the lover's contributing to the support of his beloved, without any prospect of marriage between them. 
A modern disinclination to approve as a happy ending the formation of an owner-and-slave relationship between young lovers can probably be assumed without argument as part of a general revulsion against the not-long-retired practice of slavery in the modern world, as well. And a preference for the love story which ends in marriage is well-documented for the twentieth century, both in terms of the practice of popular entertainment and in terms of the theory of comedy. ${ }^{7}$ Frye's (1953:163) description of the New Comedy love story, as transmitted by Plautus and Terence, seems fair enough: "What normally happens is that a young man wants a young woman, that his desire is resisted by some opposition, usually paternal, and that near the end of the play some twist in the plot enables the hero to have his will." But later, in the context of his argument that comedy moves towards the creation of a new society, crystallized around newly-united hero and heroine, we find once again the familiar privileging of a relatively rare version of the ancient comic plot (1953:170): "The comic ending is generally manipulated by a twist in the plot. In Roman comedy the heroine, who is usually a slave or courtesan, turns out to be the daughter of somebody respectable, so that the hero can marry her without loss of face."

This preference for marriage as the proper ending of comedy has affected how modern scholars choose to understand and describe the ancient love stories, as some have acknowledged: So Büchner (1968:90), on Plautus and Roman comedy: "The 'happy ending' of our plays and films, it is said, goes back to the New Comedy...it is only natural that comedy complications surrounding a love affair should end happily with betrothal or marriage." 8 Others, like many of those quoted at the beginning of this article, have likewise been affected, ${ }^{9}$ even those who refrain from describing a single typical plot. So, for example, Nelson (1990:54): "Two plots which recur in the comedies of Menander and his Roman imitators, Plautus and Terence, are that of the young man who violates a free woman in a fit of drunkenness at a festival and that of the youth who loves a slave-girl, flute-girl, or courtesan whom he cannot marry. Both lead to reconciliation between individual desires and the established social order. The violator of a free woman is sorry afterwards and is anxious to right the wrong by offering marriage; the lover of a slave is enraptured to discover that she is free-born, and therefore entitled to marry him." No word of recurrent plots which do not end in marriage. ${ }^{10}$

7 For the former, see, e.g., Brown \& Loy 1981; for the latter, Frye 1953:163-186.

8 "Das Happy End unserer Lustspiele und unserer Filme, hat man gesagt, geht auf die Neue Komödie zurlck...es liegt in der Natur der Sache, dass komische Verwirrung um Liebe mit Verlobung oder Hochzeit glucklich endet."

9 So Segal 1996:xiii on New Comedy: "Its locale was the city, its people the bourgeoisie, its plots romantic: boy meets / wants / has previously raped girl...all always ends well; Jack marries Jill."

10 Compare Barsby 1986:3, where the "recurring plot elements" listed for the New Comedy and its Roman adaptors are specifically those associated with an outcome in marriage: "young men have raped citizen girls at nocturnal festivals without recognising them or being recognised, children have been explosed in infancy or captured by pirates and been brought up in ignorance of their true parents..." 
The modern habit of singling out as typical the Roman-comedy girlfriend who turns out to be marriageable against original expectations, as opposed to the more frequently met with girlfriend who turns out to be unmarriageable as expected, is no doubt in part a result of the preference for the ending in marriage. In part, however, it may arise from a wish on the part of the modern reader to rescue the girl in the story from a disadvantaged status. Modern readers can be expected to have little experience of, and no great sympathy with, social systems rendering significant segments of a population unable to marry across class lines. Slavery is certainly the most unsympathetic example of such a social system, and it is very likely on this account that modern commentators so often single out, as typical of the Roman comedy love story, the slave girl found after all to be legally free and marriageable.

Ancient writers and their audience will of course have been familiar with social systems rendering significant segments of a population unable to marry across class lines, and, if not wholeheartedly sympathetic to them, at least no more than ambivalent; the modern reader's concern for the rescue from disadvantaged status of the Roman comedy slave or non-citizen girl is only partly shared in the ancient comedy, where she is sometimes so rescued - but more often not.

Anderson (1993:60-76) comments on the romanticism which marks modern interpretations of the plots of Roman comedy. Romanticism would be a good word for the view of Roman comedy plots recorded in modern discussions described in this essay, but that is not Anderson's point. In his view, New Comedy plots, and Terence's in line with these, support the interests of the family over those of the lover, channeling love regularly towards marriage, while Plautus' treatments of similar stories undermine these conservative values. In my view, so far as outcomes in the love stories played out in their comedies are concerned, there is little difference between the two Roman playwrights. Marriage is the outcome often enough to suggest that the reproduction of the traditional family is an issue in this genre, while the fact that other outcomes occur equally often suggests that this is not the only, perhaps not the chief, concern. One concern demonstrated by the thematics of the Roman comedy love story, but hardly acknowledged in modern summaries of the kind cited above, is the maintenance of the father-son relationship, with the protracted dependency inherent in the Roman system of paternal authority, in the face of the challenge to it represented by the sexual maturation of the son. In this context, a "happy ending" will be brought about by any form of continuing association between a young man and his love which does not disrupt his relationship with his family of birth.

\section{BIBLIOGRAPHY}

Albrecht, M von 1997. A history of Roman literature, Vol. I. Leiden: E. J. Brill. Anderson, W S 1975. The Roman transformation of Greek domestic comedy. $C W$ 88:171-180. 
Anderson, W S 1984. Love plots in Menander and his Roman adapters. Ramus 13:124-134.

Anderson, W S 1993. Barbarian play: Plautus' Roman comedy. Toronto: University of Toronto Press.

Ashmore, S G 1910. The comedies of Terence. Oxford: Oxford University Press.

Barsby, J 1986. Plautus' Bacchides. Warminster: Aris and Phillips.

Beacham, R C 1992. The Roman theatre and its audience. Cambridge: Harvard University Press.

Brown, J \& Loy, P 1981. Cinderella and Slippery Jack: Sex roles and social mobility themes in early musical comedy. International Journal of Women's Studies 4:507-516.

Büchner, K 1968. Römische Literaturgeschichte. Stuttgart: A Kröner.

Duckworth, G E 1952. The nature of Roman comedy. Princeton: Princeton University Press.

Fantham, E 1975. Sex, status and survival in Hellenistic Athens: A study of women in New Comedy. Phoenix 29:44-74.

Fowler, H N 1903. A history of Roman literature. New York: D. Appleton.

Frazier, F \& Sirinelli, J (edd) 1996. Plutarque: Oeuvres morales IX. Paris: Les Belles Lettres.

Frye, N 1957. The anatomy of criticism. Princeton: Princeton University Press.

Howatson, M D 1989. The Oxford companion to classical literature. Oxford: Oxford University Press.

Kauer, R \& Lindsay, W M (edd) 1926. P. Terenti Afri comoediae. Oxford: Clarendon Press.

Konstan, D 1983. Roman comedy. Ithaca: Cornell University Press.

Levin, R 1967. The double plots of Terence. CJ 62:301-305.

Lindsay, W M (ed) 1903. T. Macci Plauti comoediae. Oxford: Clarendon Press.

Moseley, N \& Hammond, M 1953. T. Macci Plauti Menaechmi. Cambridge: Harvard University Press.

Nairn, J A 1924. Authors of Rome. London: Jarrolds.

Nelson, T G A 1990. Comedy: An introduction to comedy in literature, drama, and cinema. Oxford: Oxford University Press.

Norwood, G 1932. Plautus and Terence. New York: Longman, Green.

Paratore, E 1961. Storia della letteratura latina. Florence: Sansoni.

Pichon, R 1897. Histoire de la littérature latine. Paris: Hachette.

Rose, H J 1968. Plautus. In Chambers's encyclopaedia. London: International Learning System.

Segal, E 1996. Plautus: Four comedies. Oxford: Oxford University Press.

Taladoire, B A 1989. Plaute. In Encyclopaedia universalis. Paris: Encyclopaedia Universalis France.

Wright, J 1982. Plautus. In Luce, J (ed), Ancient writers: Greece and Rome. New York: Scribner.

Zehnacker, H \& Fredouille, J-C 1993. Littérature latine. Paris: Presse universitaires de France. 